Volume: 14 Issue: 1 Year: 2017

\title{
Investigating and comparing the relationship between parental monitoring types and perceived parenting styles of the Turkish students
}

\author{
Ayşe Dilek Öğretir Özçelik ${ }^{1}$
}

\begin{abstract}
The relationship between parental monitoring and parental styles are considered as an important subject for child development field. The aim of this article is to analyze the perceptions of the adolescents about their parents' parental monitoring and parenting styles in terms of the participants' gender, family education and family jobs status. The sample size is 252 adolescents with 158 female nd 94 male students. The data were collected by the Parental Monitoring Instrument (PMI) and the Parenting Styles Scale. The sample was chosen from one Anatolian high school in Ankara, one Multi-Programme High School in Çankırı and one Multi-Programme High School in Yozgat with simple and random sampling. The results showed that there were statistically significant differences between mother acceptance/warmth and gender scores $\mathrm{t}(250)=3,281$ and mother control and gender scores $\mathrm{t}(250)=2,263 ; \mathrm{p}<0.05$. The study also analyzed the relationship between adolescent ages and grades as well as the number of children, mothers' ages and fathers' ages and the parental style with some statistically significant results. The one-way ANOVA results indicated that there are statistically significant differences between adolescents' perceptions of parental monitoring sub-scales and the mothers' parenting styles sub-scales. Except computer monitoring, in all parental monitoring sub-scales, the mothers parenting styles have shown statistically significant differences.
\end{abstract}

Keywords: Parental monitoring; Parenting Style; ANOVA; Adolescents; Turkey.

\section{Introduction}

Parental monitoring is defined as parental awareness about where their adolescents about, parents knowing of their children's activities, parents tracking of their children and parents paying attention of children's following the rules(Montemayor, 2001; Dishion and McMahon, 1998: 61; Dishion and McMahon, 1999: 236). In another definition, it is a parental activity that gives knowledge and information about adolescents friends, activities, and locations (Cottrell, et al., 2007: 328). Parental monitoring is an appropriate parental intervention technique that helps parents to determine whether their children use alcohol and drugs and to prevent their children to become friends to persons that use drugs and consume alcohol. When parents monitor their children activities more closely, they can more easily recognize the signs of their children risky behaviors and activities. Families can decrease the adolescents' risky behaviors by guiding them to the appropriate way (Stattin, et al., 2010:5). Parents can trust some new practices of family involvement techniques that include asking questions about adolescents' activities outside to home, whereabouts, what he/she is going to do, with whom he/ she spends time and create rules about parental monitoring. Most adolescents are aware of parental monitoring but they also would like control flow of

\footnotetext{
1 Associate Prof. Dr., Gazi University, Gazi Education Faculty, Primary Education Department, Early Childhood Education Programme, dilekogretir@gmail.com, ogretir@gazi.edu.tr
} 
Öğretir Özçelik, A. D. (2017). Investigating and comparing the relationship between parental monitoring types and perceived parenting styles of the Turkish students. Journal of Human Sciences, 14(1), 331-345. doi:10.14687/jhs.v14i1.4400

information to their parents (Marshall et al., 2005).Stattin and Kerr (2000) reconceptualized the parental monitoring and highlighted three processes: parental solicitation, parental control, and child disclosure (1073). There are three ways to get knowledge about adolescents' activities. First, parents directly ask their children questions. Second, a child can give information about his/her activities by his/ her will without any parental involvement. Third, parents ask questions to their children friends and peer to get an idea about their children activities (Kerr and Stattin, 2003).

Hayes et al. (2003) indicated that parental monitoring is a dynamic process. They proposed a process model of parental monitoring that includes a complex interactive process between micro and macro social levels including parents, adolescents and their environment. The process model consists of following stages. In the first stage, parents and adolescents behaviors are assessed. In the second stage, the function of this behavior and its cyclical process are hypothesized. In the third stage, the parental characteristics that may affect monitoring interactions are evaluated. Fourth, adolescent characteristics that provide information about monitoring interactions were examined. Last, the interplay of family context, peer, school, and community is considered (Hayes, et al., 2003:18).

Family members - mothers, fathers, and children - have affected their behaviors, attitudes and perceptions directly or indirectly. Indirectly, fathers may mediate and modify mother-child interaction. Similarly, women may have effects on their children indirectly through their husbands by modifying both the quality and the quantity of of father-child relationships. Also, children affect the husband-wife relationship by changing the behaviors of their parents that alters the interaction between spouses (Öğretir and Özçelik, 2008; Özçelik, 2010).

In traditional Turkish family, mothers are seen as the caregivers for children and fathers as the main providers. There have been changes in the types and structures of the Turkish families because of rapid urbanization, industrialization, and migration from the villages to the cities. There has been a tendency to have more closer bonds and intense parent-child interactions in nuclear families. Adolescents in the nuclear family are more likely enjoy greater independence, initiative and autonomy in comparison to the extended family. In extended family, individuation and seperation are restrained and mutualistic relationships are advocated. The authoritarian parental style is perceived as major characteristic of the extended family type because family members are needed to readily cooperate in order to survive tough life conditions. In the nuclear family, on the other hand, family members emphasize individualism that promotes democratic parenting styles. Extended families provide more constraints and less freedom for children and adolescents to explore their living environment and function less independently even in their daily routines. This situation often causes conflict among family members (Erkman and Ekmekci, 2011:33).

With the changing times, Turkish women increasingly involved workforce and the dual-earner families have been become more reality in the Turkish context together with a greater crossover of roles in the parenting styles. The wife/mother roles have been modified from a homemaker to coprovider that have great effects on the domestic division of labour, the role of husband/wife, and the patterns of mother-child relations. When the mother works, it may create a problem of child care between age of six and thirteen. According to numbers in 1990s, it is estimated to between two million to ten million children care for themselves. Because these children often tie their house key around their neck, they are names as latchkey kids. The studies about the latchkey kids have conflicting results. Some children perceived more insecure, neglected and rejected by their mothers. Other studies showed opposite results. Self-care of a child has been affected by various factors such as the safety of the neighborhood, the maturity of the child, and the stability of the family (McDonald and McDonald, 1994).

To a large extent, men in Turkish society have been continuing with their traditional roles as the main provider for the wife and the children. As a result, they have little responsibilities for everyday involvement in child-rearing and give less support in performing chores at the house even the women are employed. When the fathers are the head of more traditional family, they engaged 
Öğretir Özçelik, A. D. (2017). Investigating and comparing the relationship between parental monitoring types and perceived parenting styles of the Turkish students. Journal of Human Sciences, 14(1), 331-345. doi:10.14687/jhs.v14i1.4400

less in childcare activities and they were less involved in their children's schooling (Metindogan, 2015:339).

In the last decade, other researchers have begun to criticize the idea that monitoring is only active and direct behavior of the parents. Instead, they have focused on the idea that parents can get information and knowledge about their children without any effort (Ryan 2009). According to Stattin and Kerr (2000), the best way of the parental monitoring is the open communication between adolescents and parents. Instead of asking adolescent direct questions related to monitoring their behaviors, it is better that adolescents willingly talk to their parents and volunteerily give information about their activities. The new approach about the parental monitoring has emphasized that monitoring is not an activity for parents but mostly for adolescents. The new definition of parental monitoring is that adolescents volunteerily give knowledge and information about their activities in their spare time to their parents. The parental monitoring is related to family interaction and family communication. If family interaction and communication is in high quality, it means that the parental monitoring is much more successful. The high quality of intra-family interaction is an indicator for adolescents' well-being and social and cognitive development.

In the recent studies, scholars have begun to analyze the relationship between parental monitoring and adolescents' problematic and risky behaviors and deterrence effects of the parental monitoring. In one study, it is shown that there is a positive relationship between direct parental monitoring and positive adolescent behaviors (low levels of adolescents' delinquency). With the internet revolution, there has been a need for new approach about parental monitoring and new technologies (Internet, smart phones, and social media). Nowadays, parents have increasingly raised their children in wireless and new apps world. Most adults have used internet and smart phones to ease their work and social lives. However, they have neglected to use them in their relationships and communication with their children. How can parents monitor their children online without losing their confidence? Can parents become Facebook friends to their children? How can parents do their motherhood and fatherhood via smart phone screens? Those new questions will pose challenges and opportunities for the future research. It is suggested that parents should be educated and trained about new technology and parental monitoring and effective and efficient family-based communication strategies and techniques (Slee et al., 2012:509).

There are three types of monitoring. . First, direct monitoring is that parents directly ask questions to their children and use direct communication techniques for monitoring. (Metzger, et al. 2012). Second, indirect monitoring is that parents do not get any information from their children directly. Instead, they get information from other sources of monitoring such as other parents, neighbors, and peers and friends of adolescents. Restrictive monitoring is the third category of the monitoring. In this monitoring, parents enter the adolescents private space without any permission from them. (Cottrell, et al., 2007: 331).

When parent raise their children, there should be an emotional environment that fosters children personality characteristics with appropriate socialization mechanisms. According to Baumrind (1991), there are four parenting styles that are formed by child rearing's demands and responsibilities. Democratic family style encourages a child to become independent. Communication and collaboration is allowed. Families tend to be helpful and warm to their children development. In this type of family style, there is low level of conflict and high level of warmth. Authoritarian family style is characterized as restrictive and punitive style with following families' rules. This style has low level of warmth and high level of family control over a child's behaviors with strict rules. Neglecting/Disengaged family style is associated with disordered families. These families have low level of control and responsibility and low level of warmth toward their children. Last, permissive family style has high level of warmth but low level of control over their children. In this style, children are usually associated with low control over their behaviors. (Öğretir, 1999). They usually do not follow the rules and resist child rearing limitations. The most 
Öğretir Özçelik, A. D. (2017). Investigating and comparing the relationship between parental monitoring types and perceived parenting styles of the Turkish students. Journal of Human Sciences, 14(1), 331-345. doi:10.14687/jhs.v14i1.4400

approprate parenting style is democratic family style. Some researchers have found that there is relationship between positive adolescent psychology and family style (Öğretir, 2006; Demiriz and Ogretir, 2007)

The adolescents' perception of monitoring and gender has focused on whether parenting practices may have different effects on sons and daughters. The study that look at monitoring, unsupervised time, and perceived parental trust on adolescents' health risk behaviors found negotiated unsupervised time had different results of sexual activity, substance use and condom use between male and female adolescents. For male adolescents, parental monitoring is associated with less alcohol use, and consistent condom use. However, female adolescents perceived no relationship between monitoring and health risk behaviors. For adolescent girls, the perception that parents trusted them is negatively associated with sexual activity, smoking and marijuana use. For adolescent boys, perceived trust is associated only with less alcohol use. (Borawski, et al. 2003).

\section{Methodology}

The relationship between parental monitoring and parental styles are considered as an important subject for child development field. The aim of this article is to analyze the perceptions of the adolescents about their parents' parental monitoring and parenting styles in terms of the participants' gender, family education and family jobs status. The vast majority of the research in this area usually covers parenting styles and adolescents behavioral outcomes. There is a lack of research on studying the relationship between parenting monitoring and parental style typologies. Also, most studies only focus on parental monitoring by using self-reporting from mothers only perspective. It is important to analyze the parenting style and parental monitoring from different cultural values and different type of communities. This study aims to contribute a vital gap in this area not only in Turkey but also in child development literature. One of the innovations in this research is to incorporate the different types of parental monitoring into different types of parenting style.

In this study, "Personal Information" that was prepared by the researcher, "the Parental Styles Questionnaire" (Sümer and Güngör, 1999), and "the Parental Monitoring Instrument" (Cottrell,et al., 2007;Karataş and Öztürk, 2011) has been applied to the research samples of 251 adolescents with 158 female and 94 male students. The sample was chosen from one Anatolian high school in Ankara, one Multi-Programme High School in Çankırı and one Multi-Programme High School in Yozgat with simple random sampling.

In order to measure adolescents rearing styles, Sümer and Güngör (1999) "the Parental Styles Questionnaire" were used. This questionnaire that was based on Maccoby and Martin (1983)'s suggested dimensions and Lamborn et al. (1991) studies were adopted to the Turkish language by Sümer and Güngör (1999). The Questionnaire consists of 22 items in a 5-point Likert scale. It was implemented separately mother and father. It has two sub dimensions. The mother and father acceptance/warmth sub-dimension is measured by 11 items and the mother and father controlling style is measured by 11 items questions (total of 22 questions). Parent acceptance/warmth is used to measure parent accepting and understanding their children as well as their love and care toward their children. The controlling style measure parents' restrictions of their children behaviors as well as monitoring and disciplining their children (Sümer and Güngör, 1999).If a person get a high score in a sub-dimension, it shows the parental styles for mother or father. Researcher has applied simple present tense in the questions because the participants were high school students who can remember their parent styles in the past (For example, he/she controls my all behaviors).

The Parenting Style Questionnaire can be analyzed in dimensional and categorical. In dimensional basis, it has acceptance/warmth and controlling. In categorical basis, if both dimensions are above median score, it is categorized as explanatory/authoritative. If both dimensions are below median score, the parenting style is permissive/neglectful. If acceptance/warmth dimension above median and controlling below median, the parenting style is 
Öğretir Özçelik, A. D. (2017). Investigating and comparing the relationship between parental monitoring types and perceived parenting styles of the Turkish students. Journal of Human Sciences, 14(1), 331-345. doi:10.14687/ihs.v14i1.4400

permissive/indulgent. If acceptance/warmth dimension below median and controlling above median, it is categorized as authoritarian style (Sümer and Güngör, 1999).

If the scores of both sub-dimensions (acceptance/warmth and controlling) are below the median score, it is categorized as permissive/negligent. If they are above the median score, authoritarian/explanatory. There are acceptance/warmth and controlling has also other subcategories but the researcher has not used them in her analyses. Güngör (2000) provided internal consistency scores of the mother acceptance/warmth and controlling scores are .81 and .79, respectively. For father acceptance/warmth and controlling scores of internal consistence are.91 and .90 , respectively. The Cronbach's Alpha score in this study for mothers parenting style was .757. The cronbach's alpha score in this study for the fathers parenting style was .786. The Cronbach's Alpha score of the mother acceptance/warmth was .798. The Cronbach's Alpha score of father acceptance/warmth was .803. The Cronbach's Alpha score of mother control was .657. The Cronbach's Alpha score of father control was .648.

In order to measure the parents getting knowledge about risky behaviors of their children and adolescents and asking questions about their children activities, the researcher were used Cottrell, et al. (2007)'s "the Parental Monitoring Instrument". The instrument were adopted to Turkish by Karataş and Öztürk (2011). It consists of 27 items that measure how frequently parents monitor their children in the last 4 months and what kinds of monitoring strategies and techniques they were used (Stattin and Kerr, 2000). It is a 4 -point Likert scale ( $1=0$ times, $4=5$ or more times). It has seven sub-dimensions including direct monitoring (1-7 items), indirect monitoring (8-10 items), school monitoring (11-14 items), health monitoring (15-18 items), computer monitoring (19-22 items), telephone monitoring (23-24 items), and restrictive monitoring (25-27 items). Explanatory factor analysis revealed that the Instrument has seven factors and \% 48 explains total variance. All factors were above 0.69 for all seven sub-dimensions. The validity, consistency and reliability scores were high for the Turkish version of the PMI (Karataş and Öztürk 2011). The Cronbach's Alpha score for this study was .884. For the sub-dimensionsü the Cronbach's Alpha scores were as follows: Direct monitoring was .731, indirect monitoring was .815, school monitoring was .723, health monitoring was .752 , computer monitoring was .736, telephone monitoring was .749 and restrictive monitoring was .785 .

\section{Findings and Results}

Findings obtained from the study conducted to determine the relationship between parenting style and demographic variables are presented in the tables. Also, the study presents the relationship between parenting monitoring sub-scales and parenting style sub-scales in following findings and results.

Table 1. Results of Demograhic Variables of Adolescents and Their Parents

\begin{tabular}{lccc}
\hline Demograhic Variables & & $\mathbf{N ~ ( 2 5 2 )}$ & $\mathbf{\%}$ \\
\hline Adolescents Gender & Female & 158 & 62.5 \\
& Male & 94 & 37.2 \\
\hline \multirow{3}{*}{ Adolescents Age Range } & $14-15$ years old & 23 & 9.1 \\
& $16-17$ years old & 166 & 65.6 \\
& $18-19$ years old & 63 & 24.9 \\
\hline \multirow{3}{*}{ Adolescents Grades } & $9^{\text {th }}$ grade & 31 & 12.3 \\
& $10^{\text {th }}$ grade & 48 & 19.0 \\
& $11^{\text {th }}$ grade & 135 & 53.4 \\
& $12^{\text {th }}$ grade & 38 & 15.0 \\
\hline \multirow{5}{*}{ Number of Children } & One Child & 6 & 2.4 \\
& Two Child & 55 & 21.7 \\
& Three Child & 72 & 28.5 \\
& Four Child & 64 & 25.3 \\
& Five + Child & 55 & 21.7 \\
\hline
\end{tabular}


Öğretir Özçelik, A. D. (2017). Investigating and comparing the relationship between parental monitoring types and perceived parenting styles of the Turkish students. Journal of Human Sciences, 14(1), 331-345. doi:10.14687/jhs.v14i1.4400

\begin{tabular}{|c|c|c|c|}
\hline \multirow{4}{*}{ Adolescents Mothers Ages } & $30-35$ vears old & 34 & 13.4 \\
\hline & $31-35$ years old & 89 & 35.2 \\
\hline & $41-45$ years old & 79 & 31.3 \\
\hline & 46 and over & 50 & 19.8 \\
\hline \multirow{4}{*}{ Adolescents Fathers Ages } & $30-35$ years old & 11 & 4.3 \\
\hline & $31-35$ years old & 52 & 20.6 \\
\hline & $41-45$ years old & 102 & 40.3 \\
\hline & 46 and over & 87 & 34.4 \\
\hline \multirow{4}{*}{$\begin{array}{l}\text { Mothers } \\
\text { Backgrounds }\end{array}$} & No Education & 39 & 15.4 \\
\hline & Primary School & 141 & 55.7 \\
\hline & Secondary School & 48 & 19.0 \\
\hline & High School & 24 & 9.5 \\
\hline \multirow{5}{*}{$\begin{array}{l}\text { Fathers } \\
\text { Backgrounds }\end{array}$} & No Education & 8 & 3.2 \\
\hline & Primary School & 106 & 41.9 \\
\hline & Secondary School & 70 & 27.7 \\
\hline & High School & 58 & 22.9 \\
\hline & University & 10 & 4.0 \\
\hline \multirow{3}{*}{ Mothers Occupation } & Housewife & 185 & 73.1 \\
\hline & Civil Servant & 8 & 3.2 \\
\hline & Self-employed / Artisan & 59 & 23.3 \\
\hline \multirow{3}{*}{ Fathers Occupation } & Self-employed / Artisan & 136 & 53.8 \\
\hline & Civil Servant & 48 & 19.0 \\
\hline & Farmer & 68 & 26.9 \\
\hline
\end{tabular}

Out of the total number of 252 participants, there were 152 female (62.5\%) and 94 male (37.2\%) adolescent students. The results indicated that $9.1 \%$ of adolescents were 14-15 year old, $65.6 \%$ of them were $16-17$ years old and $24.9 \%$ of them were $18-19$ years old. If they were divided by their class, $9^{\text {th }}$ grades were $31(12.3 \%), 10^{\text {th }}$ grades were $48(19 \%)$, 11st grades were $135(53.4 \%)$ and 12th grades were $38(15 \%)$. Adolescents' mothers age and education status were as follows: $35.2 \%$ of them were $31-35$ years old. $55.7 \%$ of them were primary school graduates. $15.4 \%$ of them were uneducated. $55.7 \%$ of them were primary school and only $9.5 \%$ of them were high school graduates. Adolescents' fathers age and education status showed that $40.3 \%$ of them were 41-55 years old. $41.9 \%$ of them were primary, $3.2 \%$ of them were noneducated, $27.7 \%$ of them were middle school, $22.9 \%$ of them were high school and only $4.0 \%$ of them were university graduates. The majority of the adolescents' mothers were housewives $(73.1 \%)$. The majority of adolescents' fathers were self-employed $(53.8 \%)$.

Table 2. t-test Results of Parenting Styles by Gender

\begin{tabular}{lcccccc}
\hline \multicolumn{2}{l}{ Gender } & \multicolumn{2}{c}{ Female $(\mathrm{n}=158)$} & \multicolumn{2}{c}{ Male $(\mathrm{n}=94)$} & \multicolumn{2}{c}{$\mathrm{t}$-Test Results } \\
\hline Parenting Style Subscales $\overline{\bar{X}}$ & Std Dev & $\bar{X}$ & Std Dev & $\mathrm{t}$ & $\mathrm{p}$ \\
\hline $\begin{array}{l}\text { Mother Acceptance/ } \\
\text { Warmth }\end{array}$ & 42.00 & 8.29 & 38.56 & 7.62 & 3.281 & .001 \\
\hline $\begin{array}{l}\text { Mother Control } \\
\text { Father Acceptance }\end{array}$ & 34.85 & 7.19 & 32.68 & 7.66 & 2.263 & .024 \\
$\begin{array}{l}\text { Warmth } \\
\text { Father Control }\end{array}$ & 33.51 & 7.41 & 32.84 & 7.56 & .690 & .491 \\
\hline
\end{tabular}

Adolescents parenting sytle sub-dimensions (acceptance/warmth and controlling) scores by gender are given at Table 2. The comparison of mothers' acceptance/warmth scores between gender showed statistically significant results. $[\mathrm{t}(252)=3.281, \mathrm{p}<.001]$. The mean scores of mothers 
Öğretir Özçelik, A. D. (2017). Investigating and comparing the relationship between parental monitoring types and perceived parenting styles of the Turkish students. Journal of Human Sciences, 14(1), 331-345. doi:10.14687/jhs.v14i1.4400

acceptance/warmth of female adolescents $(\bar{X}=42.00)$ were much higher than the mean scores of mothers' acceptance/warmth of male adolescents $(\bar{X}=38.56)$. When the results for mothers control scores were compared, the results indicated statistically significant differences between gender $[\mathrm{t}(252)=2.263, \mathrm{p}<.024]$. The mothers control scores of females $(\bar{X}=34.85)$ were higher than the mother control scores of males $(\bar{X}=32.68)$. However, there is no statistically significant differences between father acceptance/warmth $[\mathrm{t}(252)=0.690, \mathrm{p}<.491]$ and father controlling $[\mathrm{t}(252)=1.318, \mathrm{p}<.189]$ by gender.

Table 3. One-way ANOVA Results of Parenting Styles by Adolescents Age

\begin{tabular}{|c|c|c|c|c|c|c|c|c|}
\hline Gender & $\begin{array}{r}1 \\
\text { years }\end{array}$ & $\begin{array}{l}15 \\
n=23)\end{array}$ & & $\begin{array}{l}16-17 \text { years } \\
(n=166)\end{array}$ & $\begin{array}{l}1 \\
\text { Results } \\
(n=63)\end{array}$ & years & & F-Test \\
\hline $\begin{array}{l}\text { Parenting } \\
\text { Style } \\
\text { Subscales }\end{array}$ & $\bar{X}$ & Ss & $\bar{X}$ & Ss & $\bar{X}$ & Ss & $\mathrm{F}$ & $\mathrm{p}$ \\
\hline $\begin{array}{l}\text { Mother } \\
\text { Acceptance/ } \\
\text { Warmth }\end{array}$ & 38.00 & 8.89 & 40.70 & 8.20 & 41.76 & 7.87 & 1.781 & .171 \\
\hline $\begin{array}{l}\text { Mother } \\
\text { Control }\end{array}$ & 29.65 & 7.25 & 34.25 & 7.66 & 35.07 & 6.33 & 4.839 & .009 \\
\hline $\begin{array}{l}\text { Father } \\
\text { Acceptance / } \\
\text { Warmth }\end{array}$ & 36.13 & 8.89 & 38.52 & 8.33 & 37.11 & 9.37 & 1.169 & .312 \\
\hline $\begin{array}{l}\text { Father } \\
\text { Control }\end{array}$ & 29.91 & 7.16 & 33.74 & 7.38 & 33.20 & 7.57 & 2.702 & .069 \\
\hline
\end{tabular}

It is interesting to note that there are statistically significant differences between parenting style subscales and adolescent ages. The results presented mother control sub-scale had much higher scores for $18-19$ years old $(\bar{X}=35.07)$ adolescents than $14-15$ years old $(\bar{X}=29.65)$ $[F(2,249)=2.263, p<.024]$. In other three sub-scales, there were no statistically significant differences for the adolescents age groups.

Table 4. One-way ANOVA Results of Parenting Styles by Adolescents Grades

\begin{tabular}{|c|c|c|c|c|c|c|c|c|c|c|}
\hline Gender & & $\begin{array}{c}9^{\text {th }} \text { grade } \\
(\mathrm{n}=31)\end{array}$ & & $\begin{array}{c}10^{\text {th }} \text { grade } \\
(\mathrm{n}=48)\end{array}$ & & $\begin{array}{l}\text { rade } \\
135)\end{array}$ & $\begin{array}{r}12^{\text {th }} \\
(\mathrm{n}\end{array}$ & $\begin{array}{l}\text { rade } \\
38)\end{array}$ & $\begin{array}{r}\text { F-Te } \\
\text { Resul } \\
\end{array}$ & \\
\hline $\begin{array}{l}\text { Parenting } \\
\text { Style } \\
\text { Subscales }\end{array}$ & $\overline{\bar{X}}$ & Std & $\overline{\bar{X}}$ & Std & $\overline{\bar{X}}$ & Std & $\overline{\bar{X}}$ & Std & $\mathrm{F}$ & $\mathrm{p}$ \\
\hline $\begin{array}{l}\text { Mother } \\
\text { Acceptance/ } \\
\text { Warmth }\end{array}$ & 38.87 & 7.79 & 37.87 & 9.07 & 41.37 & 7.98 & 43.50 & 7.02 & 4.355 & .005 \\
\hline $\begin{array}{l}\text { Mother } \\
\text { Control }\end{array}$ & 31.06 & 8.73 & 32.91 & 8.05 & 35.21 & 6.98 & 33.73 & 6.30 & 3.252 & .022 \\
\hline $\begin{array}{l}\text { Father } \\
\text { Acceptance } \\
\text { / Warmth }\end{array}$ & 36.77 & 8.26 & 35.47 & 9.03 & 38.84 & 8.67 & 38.86 & 8.04 & 2.143 & .095 \\
\hline $\begin{array}{l}\text { Father } \\
\text { Control }\end{array}$ & 31.41 & 7.85 & 32.97 & 7.91 & 33.96 & 7.38 & 32.63 & 6.78 & 1.141 & .333 \\
\hline
\end{tabular}


Öğretir Özçelik, A. D. (2017). Investigating and comparing the relationship between parental monitoring types and perceived parenting styles of the Turkish students. Journal of Human Sciences, 14(1), 331-345. doi:10.14687/jhs.v14i1.4400

Table 4 presented the one-way ANOVA results of parenting styles by adolescent grades. Analysis obtained from "Parenting Style Scale" seemed to be higher for mother acceptance/warmth subscale among the four groups. The $12^{\text {th }}$ grade students $(\bar{X}=43.50)$ had higher mother acceptance scores than $10^{\text {th }}(\bar{X}=37.87)$ and $9^{\text {th }}$ grade students $(\bar{X}=38.87) \quad[\mathrm{F}(2,249)=4.355, \mathrm{p}<.005]$. In mother control subscales, it has been determined that there were a statistically significant results in favor of $11^{\text {th }}$ grade students $(\bar{X}=35.21)$ than $10^{\text {th }}(\bar{X}=32.91)$ and $9^{\text {th }}(\bar{X}=31.06)$ grade students $[\mathrm{F}(2,249)=3.252, \mathrm{p}<.022]$.

Table 5. One-way ANOVA Results of Parenting Styles by the Number of Children

\begin{tabular}{|c|c|c|c|c|c|c|c|c|c|c|c|c|}
\hline Gender & $\begin{array}{l}\text { One } \\
(\mathrm{n}=6)\end{array}$ & Child & $\begin{array}{r}\text { Two } \\
\text { (n }\end{array}$ & $\begin{array}{l}\text { Child } \\
55)\end{array}$ & & $\begin{array}{l}\text { Child } \\
\text { 72) }\end{array}$ & $\begin{array}{l}\text { Four } \\
(\mathrm{n}=6\end{array}$ & & $\begin{array}{l}\text { Five } \\
(\mathrm{n}=\end{array}$ & More & $\begin{array}{r}\text { F- } \\
\text { Resu }\end{array}$ & \\
\hline $\begin{array}{l}\text { Parenting } \\
\text { Style } \\
\text { Subscales }\end{array}$ & $\bar{X}$ & Std & $\bar{X}$ & Std & $\bar{X}$ & Std & $\bar{X}$ & Std & $\bar{X}$ & Std & $\mathrm{F}$ & $\mathrm{p}$ \\
\hline $\begin{array}{l}\text { Mother } \\
\text { Acceptance/ } \\
\text { Warmth }\end{array}$ & $\begin{array}{l}35.6 \\
6\end{array}$ & 12.32 & 41.34 & 6.23 & 42.22 & 8.03 & 40.10 & $\begin{array}{c}8.7 \\
1\end{array}$ & $\begin{array}{c}39.4 \\
0\end{array}$ & 8.84 & $\begin{array}{c}1.71 \\
4\end{array}$ & .147 \\
\hline $\begin{array}{l}\text { Mother } \\
\text { Control }\end{array}$ & $\begin{array}{l}30.6 \\
6\end{array}$ & 6.88 & 35.01 & 6.65 & 34.76 & 7.56 & 33.85 & $\begin{array}{c}7.8 \\
2\end{array}$ & $\begin{array}{c}32.7 \\
0\end{array}$ & 7.52 & $\begin{array}{c}1.17 \\
1\end{array}$ & .324 \\
\hline $\begin{array}{l}\text { Father } \\
\text { Acceptance } \\
\text { / Warmth }\end{array}$ & $\begin{array}{l}33.1 \\
6\end{array}$ & 11.10 & 39.70 & 6.75 & 38.36 & 8.91 & 38.14 & $\begin{array}{c}9.0 \\
0\end{array}$ & $\begin{array}{c}35.9 \\
6\end{array}$ & 9.09 & $\begin{array}{l}1.81 \\
9\end{array}$ & .126 \\
\hline $\begin{array}{l}\text { Father } \\
\text { Control }\end{array}$ & $\begin{array}{l}27.6 \\
6\end{array}$ & 8.14 & 33.60 & 6.32 & 34.25 & 7.48 & 34.89 & $\begin{array}{l}7.4 \\
3\end{array}$ & $\begin{array}{c}30.3 \\
4\end{array}$ & 7.62 & $\begin{array}{l}4.25 \\
5\end{array}$ & .002 \\
\hline
\end{tabular}

When Table 5 is analyzed, it is observed that one-way ANOVA results were meaningful at $\mathrm{F}(2,249)=3.252, \mathrm{p}<.022$ level for father control sub-scale. The fact that one-way ANOVA results were meaningful shows that there is a relationship between the number of children and father control sub-scale. When the number of children were analyzed accordingly, it is possible to observe that if there is 5 or more child $(\bar{X}=30.34)$ in the family, interestingly the father control is decreasing in a statistically significantly than two, three or four children $(\bar{X}=34.89)$ families.

Table 6. One-way ANOVA Results of Parenting Styles by Mothers Age

\begin{tabular}{|c|c|c|c|c|c|c|c|c|c|c|}
\hline Gender & & $\begin{array}{l}35 \text { yea1 } \\
n=34)\end{array}$ & & $\begin{array}{c}36-40 \text { years } \\
(\mathrm{n}=89)\end{array}$ & & years & $\begin{array}{r}46 \\
(1\end{array}$ & $\begin{array}{l}\text { ears } \\
0)\end{array}$ & $\begin{array}{r}\text { F-T } \\
\text { Resu }\end{array}$ & \\
\hline $\begin{array}{l}\text { Parenting } \\
\text { Style } \\
\text { Subscales }\end{array}$ & $\bar{X}$ & Std & $\bar{X}$ & Std & $\bar{X}$ & Std & $\overline{\bar{X}}$ & Std & $\bar{F}$ & $\mathrm{p}$ \\
\hline $\begin{array}{l}\text { Mother } \\
\text { Acceptance/ } \\
\text { Warmth }\end{array}$ & 39.88 & 8.66 & 42.02 & 7.31 & 41.84 & 8.23 & 38.78 & 9.11 & 1.819 & .144 \\
\hline $\begin{array}{l}\text { Mother } \\
\text { Control }\end{array}$ & 33.47 & 7.38 & 35.23 & 7.46 & 34.73 & 6.83 & 31.22 & 7.75 & 3.570 & .015 \\
\hline
\end{tabular}

The comparison between mother parenting style and mother age showed statistically significant results for mother control subscale $\mathrm{F}(2,249)=3.570, \mathrm{p}<.015$. If the mothers have 46 years and older ages $(\bar{X}=31.22)$, they had lower score on mother control subscale than $36-40$ years mothers $(\bar{X}$ $=35.23)$. 
Öğretir Özçelik, A. D. (2017). Investigating and comparing the relationship between parental monitoring types and perceived parenting styles of the Turkish students. Journal of Human Sciences, 14(1), 331-345. doi:10.14687/jhs.v14i1.4400

Table 7. One-way ANOVA Results of Parenting Styles by Fathers Age

\begin{tabular}{|c|c|c|c|c|c|c|c|c|c|c|}
\hline Gender & & $\begin{array}{c}30-35 \text { years } \\
(\mathrm{n}=11)\end{array}$ & & $\begin{array}{c}36-40 \text { years } \\
(\mathrm{n}=52)\end{array}$ & & $\begin{array}{l}5 \text { years } \\
=102)\end{array}$ & & $\begin{array}{l}\text { years } \\
=87 \text { ) }\end{array}$ & $\begin{array}{r}\text { F-1 } \\
\text { Resu }\end{array}$ & \\
\hline $\begin{array}{l}\text { Parenting } \\
\text { Style } \\
\text { Subscales }\end{array}$ & $\bar{X}$ & Std & $\bar{X}$ & Std & $\bar{X}$ & Std & $\bar{X}$ & Std & $\mathrm{F}$ & $p$ \\
\hline $\begin{array}{l}\text { Father } \\
\text { Acceptance / } \\
\text { Warmth }\end{array}$ & 30.54 & 5.48 & 35.05 & 7.42 & 33.78 & 6.85 & 31.91 & 8.14 & 2.643 & .050 \\
\hline Father Control & 36.77 & 8.26 & 35.47 & 9.03 & 38.84 & 8.67 & 38.86 & 8.04 & 2.143 & .095 \\
\hline
\end{tabular}

In order to find whether there is a statistically significant result between father age and father parenting style, the study conducted one-way ANOVA analysis. The results showed that 36-40 years old fathers $(\bar{X}=35.05)$ had much higher scores for father acceptance/warmth sub-scale than $30-35$ years old fathers $(\bar{X}=30.54), \mathrm{F}(2,249)=2.643, \mathrm{p}<.050$.

Table 8. The Percentages of the Parents' Four Sub-Parenting Styles $(n=252)$

\begin{tabular}{|c|c|c|c|c|c|}
\hline $\begin{array}{c}\text { Parental } \\
\text { Styles }\end{array}$ & $\begin{array}{l}\text { Explanatory/ } \\
\text { Authoritative }\end{array}$ & $\begin{array}{l}\text { Permissive/ } \\
\text { Neglective }\end{array}$ & $\begin{array}{c}\text { Permissive/ } \\
\text { Indulgent }\end{array}$ & Authoritarian & Total \\
\hline $\begin{array}{ll}\text { Fathers } & \mathrm{n} \\
& \%\end{array}$ & $\begin{array}{c}82 \\
32.4\end{array}$ & $\begin{array}{c}64 \\
25.3\end{array}$ & $\begin{array}{c}49 \\
19.4\end{array}$ & $\begin{array}{c}57 \\
22.5\end{array}$ & $\begin{array}{c}252 \\
100.0\end{array}$ \\
\hline $\begin{array}{r}\text { Mothers } \mathrm{n} \\
\%\end{array}$ & $\begin{array}{c}74 \\
29.2\end{array}$ & $\begin{array}{c}66 \\
26.1\end{array}$ & $\begin{array}{c}54 \\
21.3\end{array}$ & $\begin{array}{c}58 \\
22.9\end{array}$ & $\begin{array}{c}252 \\
100.0\end{array}$ \\
\hline
\end{tabular}

Table 8 presented the percentages results of four parenting styles for mother and father separately. As it can be expected, the fathers were much more explanatory/authoritative and authoritarian than the mothers. The adolescents' mothers were much more permissive/neglective and permissive indulgent than the adolescents' fathers.

Table 9. t-test Results of Adolescents' Perceptions of Parental Monitoring by Gender

\begin{tabular}{ccccccccc}
\hline \multirow{2}{*}{ Parental Monitoring Sub-scales } & \multicolumn{4}{c}{ Female } & \multicolumn{4}{c}{ Male } \\
\cline { 2 - 9 } & $\mathrm{n}$ & \multirow{2}{*}{ Mean } & Std.Dev. & $\mathrm{n}$ & Mean & $\begin{array}{l}\text { Std. } \\
\text { Dev. }\end{array}$ & \multicolumn{2}{c}{$\mathrm{t}$} \\
\hline Indirect Monitoring & 158 & 12.50 & 3.69 & 94 & 11.54 & 4.27 & 1.876 & 0.396 \\
\hline Direct Monitoring & 158 & 7.92 & 2.95 & 94 & 6.56 & 2.58 & 3.701 & 0.000 \\
\hline School Monitoring & 158 & 9.10 & 2.98 & 94 & 9.25 & 3.30 & -.381 & 0.704 \\
\hline Health Monitoring & 158 & 7.99 & 3.33 & 94 & 6.97 & 3.05 & 2.412 & 0.017 \\
\hline Computer Monitoring & 158 & 6.13 & 2.80 & 94 & 6.31 & 3.09 & -.490 & 0.624 \\
\hline Telephone Monitoring & 158 & 3.27 & 1.81 & 94 & 3.02 & 1.73 & 1.105 & 0.270 \\
\hline Restrictive Monitoring & 158 & 4.17 & 2.10 & 94 & 4.07 & 2.24 & .343 & .732 \\
\hline
\end{tabular}

In the Table 9, the independent t-test for direct monitoring and gender revealed statistically significant differences between female and male students, $\mathrm{t}(250)=3,701 ; \mathrm{p}<0.000$. Female students ( $\bar{X}=7,92)$ have perceived higher direct monitoring than male students $(\bar{X}=6,56)$. The perceptions of the female $(\bar{X}=7,99)$ students about health monitoring is statistically much higher than the perceptions of the male $(\bar{X}=6,97)$ students, $\mathrm{t}(250)=2,412 ; \mathrm{p}<0.017$. 
Öğretir Özçelik, A. D. (2017). Investigating and comparing the relationship between parental monitoring types and perceived parenting styles of the Turkish students. Journal of Human Sciences, 14(1), 331-345. doi:10.14687/jhs.v14i1.4400

Table 10. The one-way ANOVA Results of Parental Monitoring Types and Mothers' Parental Styles Dimensions and Categories

\begin{tabular}{|c|c|c|c|c|c|c|}
\hline $\begin{array}{l}\text { Parental } \\
\text { Monitoring Sub- } \\
\text { scales }\end{array}$ & $\begin{array}{ll}\text { Parenting } & \text { Styles } \\
\text { (Mothers) } & \end{array}$ & $\mathrm{X}$ & Std. Deviation & $\mathrm{N}$ & $\mathrm{F}$ & $\mathrm{p}$ \\
\hline \multirow{4}{*}{ Indirect Monitoring } & $\begin{array}{l}\text { Explanatory/ } \\
\text { Authoritative }\end{array}$ & 13,12 & 3,43 & 74 & \multirow{4}{*}{7,294} & \multirow{4}{*}{, 000} \\
\hline & $\begin{array}{l}\text { Permissive/ } \\
\text { Neglective }\end{array}$ & 10,31 & 3,10 & 66 & & \\
\hline & $\begin{array}{l}\text { Permissive/ } \\
\text { Indulgent }\end{array}$ & 12,77 & 4,31 & 54 & & \\
\hline & Authoritarian & 12,37 & 4,39 & 58 & & \\
\hline \multirow{4}{*}{ Direct Monitoring } & $\begin{array}{l}\text { Explanatory/ } \\
\text { Authoritative }\end{array}$ & 8,67 & 2,65 & 74 & \multirow{4}{*}{15,544} & \multirow{4}{*}{, 000} \\
\hline & $\begin{array}{l}\text { Permissive/ } \\
\text { Neglective }\end{array}$ & 5,80 & 2,34 & 66 & & \\
\hline & $\begin{array}{l}\text { Permissive/ } \\
\text { Indulgent }\end{array}$ & 8,16 & 3,04 & 54 & & \\
\hline & Authoritarian & 6,94 & 2,65 & 58 & & \\
\hline \multirow{4}{*}{ School Monitoring } & $\begin{array}{l}\text { Explanatory/ } \\
\text { Authoritative }\end{array}$ & 10,10 & 3,05 & 74 & \multirow{4}{*}{9,508} & \multirow{4}{*}{, 000} \\
\hline & $\begin{array}{l}\text { Permissive/ } \\
\text { Neglective }\end{array}$ & 7,80 & 2,83 & 66 & & \\
\hline & $\begin{array}{l}\text { Permissive/ } \\
\text { Indulgent }\end{array}$ & 10,07 & 2,89 & 54 & & \\
\hline & Authoritarian & 8,63 & 3,01 & 58 & & \\
\hline \multirow{4}{*}{ Health Monitoring } & $\begin{array}{l}\text { Explanatory/ } \\
\text { Authoritative }\end{array}$ & 9,27 & 3,18 & 74 & \multirow{4}{*}{13,524} & \multirow{4}{*}{, 000} \\
\hline & $\begin{array}{l}\text { Permissive/ } \\
\text { Neglective }\end{array}$ & 6,06 & 2,35 & 66 & & \\
\hline & $\begin{array}{l}\text { Permissive/ } \\
\text { Indulgent }\end{array}$ & 7,74 & 3,45 & 54 & & \\
\hline & Authoritarian & 7,15 & 3,12 & 58 & & \\
\hline \multirow{4}{*}{$\begin{array}{l}\text { Computer } \\
\text { Monitoring }\end{array}$} & $\begin{array}{l}\text { Explanatory/ } \\
\text { Authoritative }\end{array}$ & 6,82 & 3,12 & 74 & \multirow{4}{*}{2,500} & \multirow{4}{*}{, 060} \\
\hline & $\begin{array}{l}\text { Permissive/ } \\
\text { Neglective }\end{array}$ & 5,60 & 2,86 & 66 & & \\
\hline & $\begin{array}{l}\text { Permissive/ } \\
\text { Indulgent }\end{array}$ & 5,83 & 2,32 & 54 & & \\
\hline & Authoritarian & 6,43 & 3,06 & 58 & & \\
\hline \multirow{4}{*}{$\begin{array}{l}\text { Telephone } \\
\text { Monitoring }\end{array}$} & $\begin{array}{l}\text { Explanatory/ } \\
\text { Authoritative }\end{array}$ & 3,60 & 1,95 & 74 & \multirow{4}{*}{4,769} & \multirow{4}{*}{,003 } \\
\hline & $\begin{array}{l}\text { Permissive/ } \\
\text { Neglective }\end{array}$ & 2,81 & 1,56 & 66 & & \\
\hline & $\begin{array}{l}\text { Permissive/ } \\
\text { Indulgent }\end{array}$ & 2,66 & 1,54 & 54 & & \\
\hline & Authoritarian & 3,53 & 1,83 & 58 & & \\
\hline \multirow{4}{*}{$\begin{array}{l}\text { Restrictive } \\
\text { Monitoring }\end{array}$} & $\begin{array}{l}\text { Explanatory/ } \\
\text { Authoritative }\end{array}$ & 4,02 & 2,01 & 74 & \multirow{4}{*}{5,060} & \multirow{4}{*}{,002 } \\
\hline & $\begin{array}{l}\text { Permissive/ } \\
\text { Neglective }\end{array}$ & 4,31 & 2,50 & 66 & & \\
\hline & $\begin{array}{l}\text { Permissive/ } \\
\text { Indulgent }\end{array}$ & 3,31 & ,79 & 54 & & \\
\hline & Authoritarian & 4,82 & 2,52 & 58 & & \\
\hline
\end{tabular}


Öğretir Özçelik, A. D. (2017). Investigating and comparing the relationship between parental monitoring types and perceived parenting styles of the Turkish students. Journal of Human Sciences, 14(1), 331-345. doi:10.14687/jhs.v14i1.4400

The means and standard deviations results of the parental monitoring categories and the mothers' parenting style types were presented in order to analyze the comparison of parenting styles and parental monitoring by using one-way ANOVA. The analysis indicated that there were statistically significant difference between adolescents' perceptions of all except computer parental monitoring and the mothers' parenting styles in Table 10. [Wilks' Lambda $=0.687, \mathrm{~F}=(9$, $273)=4,619, \mathrm{p}<.05$. Only computer monitoring has shown no statistically significant difference for the parenting styles $[F(3,248)=2,500, p>.05]$. The reason why the computer monitoring has no statistically significant difference may be related to the mothers' digital abilities and competences. Most mothers have very little knowledge about how to monitor their children on computer.

In other six parenting monitoring types, the difference between four groups is statistically significant for indirect monitoring $[\mathrm{F}(3,248)=7,294, \mathrm{p}<.05]$. The Scheffe test results showed that the mean score of indirect monitoring of mothers' who are explanatory/authoritative $(\bar{X}=13,12)$ is much higher than the mean score of indirect monitoring of mothers who permissive/neglectful ( $\bar{X}=10,31)$. The other results can be seen at the above table 10 .

\section{Discussion}

Parental involvement and intra-family communication are important factors to design parental intervention and to change family dynamics and parents behaviors. When parents are changed their behaviors in positive ways, the adolescents problematic behaviors such as delinquency, bullying, and risky sexual activities begin to decrease. In child development field, parents can positively affect adolescents' developmental and behavioral problems and this can be explained by the parenting style. In Turkey, there is little research on parenting styles and family intervention techniques. In addition, it is relatively low level of studies on parenting styles and parental monitoring. The purpose of the current study was to determine whether the association between parental monitoring types and parenting styles dimensions of the Turkish adolescents' selfreported perceptions.

This study makes contribution on previous research of Kerr and Stattin (2000) on parental monitoring by surveying adolescents' about the relationship with their parents. In other studies about the impact of parental monitoring, parental communication and parenting style, Huebner and Howell (2003) found no direct relationship between parental communication, parenting style or the demographic characteristics of gender, age, or race on the sexual risk behaviors (defined as number of lifetime sexual partners and condom use during last sexual intercourse). In another study, Pettus (2003) found that parental actions of monitoring were as important women as for men. In their interactions with their parents, men tended to have more positively influenced by their parents on men's social adjustment and connection to the college. For women respondents, the acceptance by their peer seemed to be more important for their performance and satisfaction in college (113).

Parenting styles and parental monitoring have been mostly studied in Western contexts. The current study is important contribution for research about non-Western cultures, parenting monitoring and parenting styles. Most Western cultures emphasize "individualistic" traits that stress independence, individual achievement, self-reliance, and competitiveness. Most Eastern cultures can be grouped under collectivistic that seek to foster interdependence, respect group norms, harmony and elders and even put families' needs and desires before children's own (Ogretir, 2008). Also, parenting styles may have different constructs for Western and non-Western cultures. In the Western cultures, authoritarian parenting style connotes with "parental rejection and lack of warmth" and even in some situation negative outcomes with physical strictness and punishment. In the Eastern cultures, authoritarian style can be tolerated by the children "without the negative connotations and consequences" (Venkatraman, et al., 2010: 90-92). 
Öğretir Özçelik, A. D. (2017). Investigating and comparing the relationship between parental monitoring types and perceived parenting styles of the Turkish students. Journal of Human Sciences, 14(1), 331-345. doi:10.14687/jhs.v14i1.4400

Almost in all studies about parental monitoring, the researchers found statistically significant differences between gender. It was indicated that mothers are more active and more successful monitors than fathers (Belle and Philips, 2010: 69).

The comparison of parenting style and gender, family education and family job status has given interesting results. The study is examined interactions between the parenting style dimensions and parents' socioeconomic status (education and job) and gender. The results showed societybased family approach that can explain why mothers acceptance/warmth and mother controlling scores were higher for female than male students. Culturally, the Turkish adolescents perceived their mothers' both accepting and controlling. In the Western culture, the scientific studies have shown that the parents controlling can restrict adolescents' freedom, autonomy and independence. However, in the "high-context cultures" (collectivist cultures) (Öğretir, 2008) like Turkey, it is possible to interpret that the parents controlling has a positive effect to improve family relations and communication. The findings also supports by cross-cultural studies that found out the coexistence of strong parental affection/warmth and controlling (Kağıtçıbaş1, 2007). The interdependent family model reiterates that "late adolescents consent that a person can be both autonomous and closely attached to someone" (Kagitcibasi, 2005: 416).

The findings about parental monitoring demonstrate that a pattern of direct and health monitoring for females than males. This is an indication for the protective association of parental monitoring with eating habits and healthy lifestyle. The most interesting finding to emerge from this analysis was a trend for parental monitoring to be related to females than males. Female adolescents were perceived more parental monitoring than male adolescents. This shows that parents may need to be more vigilant to protect their female children engaging in deviant behaviors.

\section{Conclusion}

Parenting can be difficult today for several reasons, some of which is that work and parent roles are often conflict, society-wide conditions affect the parent-child relationship and the parenting practice of monitoring and peer relations have an influence on parent/child attachment.

Strength of this study includes operationalizing monitoring variables that focus on seven types of monitoring. This study also has several limitations. The study was cross-sectional; therefore, it was not possible to examine how links between measures of monitoring and parenting style change over time. In addition, most of data in this study were only gained through self-report measures. A multi-method approach to assessing parental monitoring and parenting style would have been more informative. In conclusion, the present study provides evidence to support the link between parental monitoring and parenting styles especially for mothers. The one-way ANOVA results for mothers between parental monitoring and parenting style variables were statistically significant.

This study suggests some important lessons for parents/teachers/school counselors, etc. First, trust and communication are important element for promoting improved parental monitoring. Teachers, schools and peers may have impact on effective and reciprocal parental monitoring if they address issues of trust and communication. Second, teachers, schools, counselors, and peers should involve more on parental monitoring in order to mitigate externalizing behaviors of adolescents. If parents know their friends, where their teen is, and having a check in time, it is possible to decrease delinquent behaviors. Third, teachers, school administration and counselors should consider developing a comprehensive parental monitoring program in order to address the risky behaviors of adolescents.

The results of this study can be used to develop parental monitoring programmes aimed at supporting adolescents' attachment needs for security and autonomy. As a result, adolescents enhance their overall adjustments and improve their ability to realize more academic and social success. An increased understanding of parenting style and parenting monitoring can assist parents 
Öğretir Özçelik, A. D. (2017). Investigating and comparing the relationship between parental monitoring types and perceived parenting styles of the Turkish students. Journal of Human Sciences, 14(1), 331-345. doi:10.14687/jhs.v14i1.4400

in focusing more on attachment and developmental issues that include trust, relationship building, and self-esteem issues that are important for adolescent population.

\section{References}

Baumrind, D. (1991). "The influence of parenting style on adolescent competence and substance use", Journal of Early Adolescence, 11, 56-95.

Belle, Deborah and Brenda Phillips. (2010). "Impediments to Parental Monitoring in the AfterSchool Hours: A Qualitative Analysis", Vincent Guilamo-Ramos, James Jaccard and Patricia Dittus (eds.), Parental Monitoring of Adolescents: Current Perspectives for Researchers and Practitioners, Columbia University Press: New York, 67-90.

Borawski, EA, CE levers-Landis, LD Lovegreen and ES Trapl. (2003) "Parental monitoring, negotiated unsupervised time, and parental trust: the role of perceived parenting practices in adolescent health risk behaviors", Journal of Adolescents Health, 33 (2), Aug 2003, 60-70.

Cottrell, S. A., Branstetter, S., Cottrell, L., Harris, C. V., Rishel, C. and Stanton, B. F. (2007). "Development and validation of a parental monitoring instrument: measuring how parents monitor adolescents' activities and risk behaviors", Family Journal, vol. 15, no. 4, October 2007, 328-335.

Demiriz, S. and Öğretir, A. D. (2007). "Alt ve Üst Sosyo-Ekonomik Düzeydeki 10 Yaş Çocuklarının Anne Tutumlarının İncelenmesi”, Kastamonu Ë̆itim Dergisi, 15(1), 105-122.

Dishion, T. J. and McMahon, R. J. (1998). "Parental monitoring and the prevention of child and adolescent problem behavior: A conceptual and empirical formulation", Clinical Child and Family Psychology Review, 1(1), 61-75.

Dishion, T. J. and Mcmahon, R. J. (1999). Parental monitoring and the prevention of child and adolescent problem behavior: A conceptual and empirical formulation. Research meeting on drug abuse prevention through family interventions, R.S. Ashery (ed.), NIDA Research Monograph, 177, Washington D.C.: Government Printing Office, 229 - 259.

Erkman, Fatos and Ekmekci, Aysen Y. (2011). "Congruence of Parent and Child Perceptions of Parental Acceptance-Rejection", Elias Kourkoutas and Fatos Erkman (ed.), Interpersonal Acceptance and Rejection: Social, Emotional, and Educational Contexts, Boca Raton: Brown Walker Press, 23-35.

Hayes, L., Hudson, A. and Matthews, J.,2003, "Parental monitoring: A process model of parentadolescent interaction", Behaviour Change, 20(1), 13-24.

Huebner, AJ and LW Howell. (2003). "Examining the Relationship Between Adolescent Sexual Risk-taking and Perceptions of Monitoring, Communication, and Parenting Style", Journal of Adolescent Health, August 2003, 33 (2), 71-8.

Güngör, D. (2000). Bağlanma Stillerinin ve Zihinsel modellerin Kuşaklararası Aktarımında Anababalık Stillerinin Rolü. Yayınlanmamış Doktora Tezi, Ankara Üniversitesi, Sosyal Bilimler Enstitüsü, Ankara.

Kagitcibasi, C. (2005). Autonomy and Relatedness in Cultural Context: Implications for Self and Family, Journal of Cross-Cultural Psychology, 36; 403-422. http://www.uk.sagepub.com/pricefamchnge4e/study/articles/13/Kagitcibasi.pdf

(Retrieved on 01.01.2017).

Kagitcibasi, C. (2007). Family, self, and human development across cultures: Theory and applications. 2nd ed. Mahwah, NJ: Lawrence Erlbaum Associates.

Karataş, H. and Öztürk,C. (2011). “Anne-Baba İzleme Ölçeğinin psikometrik özellikleri”, Anadolu Psikiyatri Dergisi, 12, 151-157.

Kerr, M. and Stattin, H. (2000). "What parents know, how they know it, and several forms of Adolescents adjustment: Further evidence for a reinterpretation of monitoring", Developmental Psychology, 36, 366-380. 
Öğretir Özçelik, A. D. (2017). Investigating and comparing the relationship between parental monitoring types and perceived parenting styles of the Turkish students. Journal of Human Sciences, 14(1), 331-345. doi:10.14687/jhs.v14i1.4400

Lamborn, S. D., Mounts, N. S., Steinberg, L. and Dornbusch, S. M. (1991)."Patterns of Competence and adjustment among adolescents from authoritative, authoritarian, indulgent, and neglectful families", Child Development, 62,1049-1065.

Li X, Stanton B., and Feigelman, S. (2000). "Impact of perceived parental monitoring on adolescent risk behavior over 4 years", Journal Adolescent Health, 27 (6), 49-56.

Maccoby, E. E. and Martin, J. A. (1983). "Socialization in the context of the family: Parent-child interaction", P.H.Mussen(Ed.) and E. M. Hetherington(Vol. Ed.), Handbook of childpsychology: Vol. 4. Socialization, personality, and social development, $4^{\text {th }}$ ed., New York: Wiley, 1-101.

Marshall, S. K., Tilton-Weaver, L. C., and Bosdet, L. (2005). "Information management: Considering adolescents' regulation of parental knowledge", Journal of Adolescence, 28, 633647.

McDonald, Cleveland and Philip McDonald. (2008). Creating a Successful Christian Marriage, 4th ed., Michigan: Baker Academic.

Metindogan, A. (2015). "Fathering in Turkey", Jaipaul L. Roopnarine (ed.), Fathers Across Cultures: The Importance, Roles, and Diverse Practices of Dads, Santa Barbara, CA: ABC-CLIO LLC, 327349.

Metzger, A., C. Ice and L. Cottrell, 2012, "But I Trust My Teen: Parents' Attitudes and Response to a Parental Monitoring Intervention", AIDS Research and Treatment, Volume 2012 (2012), Article ID 396163, 10 pages, viewed 21 December 2014, from http://www.hindawi.com/journals/art/2012/396163/(Retrieved on 01.01.2017).

Montemayor, R. (2001).“Parental monitoring”, J. V. Lerner, R. M. Lerner and J. Finkelstein (Eds.), Adolescence in America: An encyclopedia, Santa Barbara, CA: ABC-CLIO, Vol. II, pp. 481-484.

Öğretir, A. D. (2008). “The Relationship Between Culture and the Conflict Resolution Styles: A Survey Method and a Statistical Analysis" Middle-East Journal of Scientific Research, 3 (2): 96104, http://www.idosi.org/mejsr/mejsr3(2)/9.pdf (Retrieved on 01.01.2017).

Öğretir, A. D. (1999). Alt ve Üst Sosyo-Ekonomik Düzeyde Altı Yaş Cocuklarmm Sosyal Oyun Davransslaryla Ana-Baba Tutumlarn Arasindaki Ilişkinin İncelenmesi, Master Tezi, Gazi Üniversitesi, Sosyal Bilimler Enstitüsü, Çocuk Gelişimi ve Ev Ekonomisi Eğitimi Anabilim Dal, Ankara.

Öğretir, A. D. (2006). "Duygusal Gelişim ve Eğitim: Sözsüz İletişim, Problem Çözme ve Sosyal Beceriler", Süleyman Demirel Üniversitesi Sosyal Bilimler Dergisi, 14, Mayıs 2006, 1-15.

Öğretir, A. D. ve S. OOzçelik. (2008). "The Study Of Ethnocentrism, Stereotype And Prejudice: Psycho- Analytical And Psycho-Dynamic Theories" Journal Of Qafqaz. University, 24 Fall 2008, 236-244. http://journal.qu.edu.az/content.php?page $=$ article\&j id=1006\&s id $=103 \& \mathrm{a}$ id $=79$ (Retrieved on 01.01.2017).

Öğretir, A. D., (2008). The Relationship Between Culture and the Conflict Resolution Styles: A Survey Method and a Statistical Analysis, Middle-East Journal of Scientific Research, ISSN 19909233, 3 (2), 96-104. https://www.idosi.org/mejsr/mejsr3(2)/9.pdf (Retrieved on 01.01.2017).

Özçelik, S. (2010). "The Analysis of Intergroup Bias: Socio-Biology, Evolutionary Psychology and Social Cognition Theornes", Journal Of Qafqaz University, number: 30 Fall 2010, 1-9. http:/ /journal.qu.edu.az/content.php?page $=$ article\&j $\mathrm{id}=1050 \& \mathrm{~s}$ id $=105 \& \mathrm{a}$ id $=669$ (Retrieved on 01.01.2017).

Pettus, K. R. (2006) The relationship of parental monitoring to community college student adjustment and acbievement: Differences by gender, ethnicity, parental education level, and student residence (Order No. 3224467). Available from ProQuest Dissertations \& Theses Global.(305274653). Retrieved from http://search.proquest.com.mutex.gmu.edu/docview/305274653?accountid=14541

Ryan, J. A. (2009). Consolidation of Parental Monitoring Variables and Scales: Preliminary Evidence for Construct Validity. Master of Science in Psychology, West Virginia 
Öğretir Özçelik, A. D. (2017). Investigating and comparing the relationship between parental monitoring types and perceived parenting styles of the Turkish students. Journal of Human Sciences, 14(1), 331-345. doi:10.14687/ihs.v14i1.4400

Slee, P. T., M. Campbell and B. Spears. (2012). Child, Adolescent and Family Development, Cambridge University Press: New York, $3^{\text {rd }}$ Ed.

Stattin, H. and Kerr M. (2000). "Parental monitoring: a reinterpretation", Child Development ,71, 1072-1085.

Stattin, H., Kerr, M. and Tilton-Weaver, L. (2010)“A critical examination of the research", Guilamo-Ramos,V., Jaccard, J. and Dittus, P. (Ed.),Parental Monitoring of Adolescents: Current Perspectives for Researchers and Practitioners, New York, NY, USA: Columbia University Press, 338, Retrievedfromhttp://www.ebrary.com

Sümer, N. and Güngör, D. (1999)."Çocuk yetiştirme stillerinin baglanma stilleri, benlik degerlendirmeleri ve yakın ilişkiler üzerindeki etkisi”, Türk Psikoloji Dergisi,14, 35-58.

Venkatraman, Sonia, Thomas J. Dishion, Jeff Kishner, and Fronçois Poulin. (2010). "CrossCultural Analysis of Parental Monitoring and Adolescent Problem Behavior: Theoretical Challenges of Model Replication When East Meets West", Vincent Guilamo-Ramos, James Jaccard and Patricia Dittus (eds.), Parental Monitoring of Adolescents: Current Perspectives for Researchers and Practitioners, Columbia University Press: New York, 90-124. 